\title{
The Interaction between Public Sector Wage, Inflation and Exchange Rate Volatility in Ghana
}

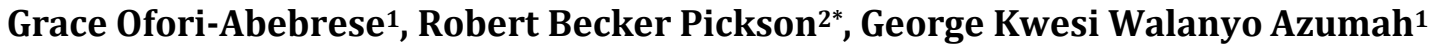 \\ ${ }^{1}$ Kwame Nkrumah University of Science and Technology, Kumasi, Ghana \\ ${ }^{2}$ College of Economics and Management, Sichuan Agricultural University, Chengdu, China \\ Email: *myselfpickson@yahoo.com
}

How to cite this paper: Ofori-Abebrese, G., Pickson, R.B. and Azumah, G.K.W. (2017) The Interaction between Public Sector Wage, Inflation and Exchange Rate Volatility in Ghana. Theoretical Economics Letters, 7, 365-380.

https://doi.org/10.4236/tel.2017.73028

Received: February 7, 2017

Accepted: March 24, 2017

Published: March 27, 2017

Copyright $\odot 2017$ by authors and Scientific Research Publishing Inc. This work is licensed under the Creative Commons Attribution International License (CC BY 4.0).

http://creativecommons.org/licenses/by/4.0/

\begin{abstract}
Continuous depreciation of the cedi has been in the orbit of concern of policy makers for time immemorial. This is because, in spite of many policy actions to restore the continuous depreciation of the cedi amidst wage hikes and inflation, the efforts of policy makers seem to thwart in vain. The ARDL method was empirically used to determine whether the rising public sector wage bill and inflation have any impact on the value of the cedi over the period 1986 to 2014. The study discovered that inflation, money supply, interest rate and public wage bill have significant impact on exchange rate in the Ghanaian economy. The outcome of this study postulated that exchange rate determination in Ghana is also a fiscal phenomenon in spite of the significant and domineering role played by monetary expansion. Based on this information, the paper proposed that equal attention must be accorded both fiscal and monetary policy in exchange rate stabilization. It, therefore, suggested that there must be a purely independent central bank; devoid of political appointments and interference to carry out its mandate with free hands. An independent non-political fiscal body like the monetary policy committee under Bank of Ghana must also be established under the same body independent of the Ministry of Finance to ensure wage sustainability through the negotiation of public sector wage adjustment subject to budgetary constraints.
\end{abstract}

\section{Keywords}

Public Sector Wage Bill, Inflation, Exchange Rate, Government Fiscal Deficit, Money Supply

\section{Introduction}

High wage bill, high rate of inflation and continuous depreciation of the cedi have 
been a great national concern over the years. The situation has become alarming in recent times sparking a lot of debates among researchers, policy analyst, academicians, politicians and the public at large concerning the causes and the link between these important macro variables. For instance, a study conducted by Parsley and Wei [1] in 96 cities in the USA and Japan identified a positive and significant correlation between exchange rate volatility and price dispersion. This is confirmed by Bleaney [2] who also found a significant positive relationship between inflation and real exchange rate. However, Krugman [3] cited in Albuquerque and Portugal [4] did not find any connection between exchange rate and macroeconomic variables. Flood and Rose [5] also cited in Albuquerque and Portugal [4] did not find any trade-off between inflation and exchange rate. Drawing from Post-Keynesian and Structuralist inflation theories, the fall in inflation rate was primarily as a result of wage declines, fall in prices of products produced by international competition and impacts of the exchange rate [6]. Hence, inflation is the outcome of cost pressures coming from wages, prices of commodities, the real exchange rate and the resistance of wage to previous inflation. They further maintained that wages in a way also respond to changes in exchange rate and the falling prices of imports that exert pressure on domestic workers.

Some analysts such as Marfo [7], Bawumia [8] and Bemanke et al. [9] attributed continuous currency depreciation and rising price levels to economic mismanagement, corruption, and high fiscal deficit among others. Others like Asiama et al. [10] among others argued that the overwhelming situation could be the result of the high wage bill aggravated by the introduction of the Single Spine Salary Structure (SSSS) implemented in 2009, and increase in the volume of imports with a fall in export value. According to the Ministry of Finance (2013 [11]), the wage bill has more than tripled over the period 2009-2012. It increased from GHC2.9b ( $\$ 2.58 \mathrm{~b}$ ) in 2009 representing $62 \%$ of tax revenue to GHC9b (\$5b) in 2012. The 2012 wage bill forms $73 \%$ of tax revenue including salary arrears, $40.8 \%$ of total expenditure and $11.9 \%$ of GDP. IMF [12] also noted that Ghana's wage bill as a percentage of GDP is higher than the average wage bill in Sub-Sahara Africa between 2000 and 2004 and higher than that of ECOWAS between 1990 and 2004. Inflation has also been on the ascendency and continues to fluctuate rising from $10.9 \%$ in 2007 to $16.5 \%$ in 2008 and $19.3 \%$ in 2009 and stands at $17 \%$ at the end of 2014 . The exchange rate depreciation increased from $15.8 \%$ in 2008 to $18 \%$ in 2012 and $19.4 \%$ in the first quarter of 2014 and at the end of 2014, it jumped to $31.2 \%$.

It is undeniable fact, and clear that Ghana's wage bill constitutes the highest proportion of public expenditure in recent years. If an increase in government expenditure can lead to an increase in aggregate demand raising price levels with its attendance implications on the private sector, then an increase in wages should be a great concern. Most measures to resolve the depreciation challenge has emphasized on the use of monetary measures without giving fiscal measures of which wage is one much consideration. Canzoneri et al. [13] have explained that price inflation targeting; thus, fixing price to effect movements in interest 
rate has received more attention than wage inflation targeting-rule that makes interest rate responds only to wage movements which is an obvious alternative.

To stabilize price levels and depreciation of the cedi, policy makers have tried measures such as increase in the Bank of Ghana's prime rate, contraction in money supply, and increase the supply of the dollar, etc. Some proponents and theories have advocated for the use of some measures to solve the problem with no regards to the role of wage hikes. One of such theories is Friedman's [14] quantity theory of money cited in Ekanayake [15] that explains inflation phenomenon as a result of too much money chasing too few goods. The monetarists approach tags a unique price level inflation as, always, and everywhere, a monetary phenomenon which emanates from a rise in money supply. This is in variance with Keynes theory that, prices increase over any increase in production in the absence of excess demand in the market due to the existence of pressure from organized labour unions for increased wages. The employers resolve to transfer the increased wages into prices culminating into wage-price spiral, which triggers inflation relating also to the cost-push school of thought. Thus, contrary to the monetarists' view, Keynes and the Structuralists affirm inflation is not as a result of increased money supply but increase in wages, increase in import prices, increase in commodity prices, exchange rate effects etc.

Some critical questions that must be asked are whether high wages increase price levels in Ghana, do high prices increase imports leading to a fall in the value of the cedi? What is the effect of an increase in the rate of inflation on the exchange rate, are wages, inflation, and the exchange rate related in anyway? What is the effect of changes in public sector wage on the exchange rate? To provide answers to these questions, there is, therefore, the need to investigate empirically if ballooning public sector wage bill has any hand in the inflation-exchange rate volatility in Ghana.

\section{Review of Related Literature}

Exchange rate (the price of one currency in terms of another) is determined by the interaction of demand and supply in respect of foreign currency in any particular period of time [16]. It is noted in her work that when the domestic currency (cedi) appreciates, exports become expensive and imports become relatively cheap. She argued that fundamentally, anything that leads to a rise in the demand for domestic goods relative to foreign goods results in an increase in the demand for domestic currency and a decrease in its supply causing it to appreciate. Inferring from this argument, one can narrow it down to price levels, hence inflation is the basic cause of any change in the demand for and supply of both foreign and domestic goods ceteris paribus. Thus, increase in price levels (inflation) increases the demand for foreign goods (imports) accompanied by the depreciation of the domestic currency.

Again, according to Bilson [17], an increase in the rate of inflation will lead to an increase in demand for money and an increase in expenditure on goods which results in an increase in prices. The currency is expected to depreciate due 
to the price rise to maintain the purchasing power parity. This assertion is based on a simple theoretical monetary model fundamental to the behavioral equation of the monetary approach assumed to be of Cagan functional form.

Roos [18] quoted in Osei-Assibey [19] categorizes exchange rate depreciation theories into two. They are those explaining short run movements (capital flows-asset models) and long run movements (capital flows and current accounts-balance of payment models). The asset approach is based on the assumption that assets traded in an efficient market predict the spot rate value which changes like any other asset. The asset models are broadly divided into two main types; the monetary approach and the portfolio balance. The monetary approach postulates that exchange rate is determined by the relative price levels of two countries. This also relates to the purchasing power parity (interest rates parity) which contends that it is the differences in prices (interest rates) among countries that cause exchange rates to move. These relative price levels are subsequently determined by the demand and supply of money. Thus, increase in money supply other things being equal leads to proportionate fall in the value of the domestic currency due to increased domestic prices. The balance of payment approach focuses on current account as a determinant of exchange rate. Current account deficit (surplus) mirrors depreciation (appreciation) of exchange rate which also relates to the absorption approach. In consequent, high inflation countries tend to experience depreciating currencies.

Abradu-Otoo and Bawumia [20] in an attempt to ascertain the relationship between money growth, inflation, and exchange rate in Ghana employed an error-correction mechanism and cointegration analysis. Monthly data series covering the period 1983-1999 were used. The results of the study suggested a long run relationship between inflation, money supply growth, cedi depreciation and real income. It was also found that there is a positive correlation between exchange rate, money supply growth and inflation in Ghana but found inflation to be inversely related to real income.

Mumuni and Owusu-Afriyie [21] in their study, explored the factors that drive exchange rate in Ghana specifically the cedi/dollar rate. They employed cointegration techniques and error correction model in their analysis. The outcome of the study contended that the dynamics in the cedi/dollar rate are significantly determined by the rate of inflation and the treasury bill rate among others.

Kashif [22] studied the long run relationship between inflation and exchange rates in Pakistan using Ordinary Least Square (OLS) model and a monthly data from 1970-2009. He considered inflation as the explanatory variable and the exchange rate as the explained variable per contemporary study. The study maintained that there is a strong negative correlation between inflation and exchange rate. This finding may suggest and render invalid the argument of imported inflation. He also found that a rise or fall in the value of a currency is caused by the macroeconomic variables such as the interest rates, money supply and inflation. In effect, changes in the spot and forward exchange rates are the results of changes in inflation. 
Madesha et al. [23] using Granger causality test empirically probed the relationship between exchange rate and inflation in Zimbabwe. An annual data for the period 1980 to 2007 was used. The findings of this study indicated that inflation and exchange rate Granger-cause each other and thus have a long run relationship.

Similarly, to explore exchange rate determinants in Ghana with much emphasis on inflation, Immurana et al. [24] using an Autoregressive Distributed Lag (ARDL) to cointegration model with an annual data series covering the period 1985-2010 maintained that inflation significantly affects exchange rate positively in the long run but affects it negatively in the short run.

Exchange rate is a principal indicator of economic growth of a country and its variability has a significant impact on international trade. Ali, Mahmood and Bashir [25] attempted to investigate the impact of inflation, interest rate, and money supply on exchange rate volatility in Pakistan using monthly data for the period ranging from July, 2000 to June, 2009. The authors employed Johansen Cointegration approach and Vector Error Correction Model (VECM) to establish that there existed short run and long run relationships between inflation and exchange rate volatility. The study also indicated that money supply growth and a rise in interest rate raises the general price level which in effect leads to exchange rate volatility.

\section{Study Methodology}

\subsection{Model Specification}

Based on a simple theoretical monetary model of determining exchange rate starting with the demand for money function as explained by Bilson [17], the empirical testable model for exchange rate determination for Ghana was formulated in the following form:

$\operatorname{lnEXRDEP} P_{t}=\gamma_{0}+\gamma_{1} \operatorname{lnINFL}_{t}+\gamma_{2} \operatorname{lnINT}_{t}+\gamma_{3} M_{t}^{s}+\gamma_{4} \operatorname{lnPWB_{t}}+\gamma_{5} \ln P W B E_{t}+\mu_{t}$

where $E X R D E P=$ exchange rate depreciation of the cedi, INFL = inflation rate which is Ghana's general consumer price levels, $P W B=$ public sector wage bill as percentage of GDP, $P W B E=$ public sector wage bill as percentage of total government expenditure, INT $=$ interest rate representing monetary policy rate, $M^{\mathcal{S}}$ $=$ broad money supply $(\mathrm{M} 2+), \ln =$ notation of natural logarithm, $\gamma_{0}=$ constant intercept, and $\mu_{t}=$ stochastic error term that captures all relevant potential variables that might have been omitted from the model. $\gamma_{1}, \gamma_{2}, \gamma_{3}, \gamma_{4}$, and $\gamma_{5}$ are the parameter elasticity coefficients, and $t$ is the time subscript.

\subsection{Type and Sources of Data}

The study used secondary data covering the period 1986-2014. The sample period chosen for the study was based on the availability of data for all the variables. Annually collated time series data on inflation, interest rate, money supply and exchange rate depreciation were obtained from Bank of Ghana (BoG) database. Public sector wage bill was acquired from Institute of Statistical, Social 
and Economic Research (ISSER) and the IMF, and government expenditure was calculated from the Ministry of Finance data by the International Monetary Fund (IMF).

\subsection{Variables Definition and Expected Signs}

After specifying the exchange rate model for the study, the variables used in the model were defined, and their measurements and expected signs explored under this section. Exchange rate depreciation is the dependent variable and is assumed to be the depreciation rate of the cedi in this study. The real effective exchange rate is the measure of the relative strength of the domestic currency against a basket of other foreign currencies. This provides a uniform measure of change in exchange rate in all countries irrespective of the choice of the exchange rate regime. However, as this study was concerned with the volatility in exchange rate; depreciation rate was rather chosen. To assess the effects, exchange rate depreciation was regressed on macroeconomic variables below.

Public sector wage bill-GDP as an independent variable in the model is the total government expenses on wages and salaries only in cash expressed as a percentage of GDP. This is based on the World Bank [26] narrow definition. The wages and salaries are government total remuneration in cash and kind and social contributions paid on behalf of employees as captured by IMF [27] and OECD [28]. The public wage bill used in the study combines both definitions as the data is obtained from different sources. Public wage bill as a percentage of GDP is used because it grows in proportion to GDP. The wage bill is expected to relate positively to exchange rate depreciation drawing from the post-Keynesian simple pricing model. Again, Public sector wage bill as a percentage of total government expenditure is also used as independent control variable. It is expected to have similar intuition as public sector wage bill-GDP.

Interest rate represents the Bank of Ghana policy rate. An increase in the interest rate is supposed to cause an appreciation in the exchange rate. According to Keynes [29] increase in interest rate reduces the demand for money and as a result, this may lead to an appreciation in the cedi. Hence, a positive relationship between interest rate and exchange rate is expected in this study.

Money supply which is also an independent variable is the broad money supply (M2+) as defined by Bank of Ghana. Also, per the simple theoretical monetary model, an increase in money supply is expected to depreciate the cedi.

Inflation represents the general consumer price index. Theoretically, inflation is expected to have a depreciating effect on the cedi; hence, a positive relationship based on the monetary approach to exchange rate determination.

\subsection{Estimation Techniques}

Augmented Dickey-Fuller (ADF) was adopted to ensure the reliability of analyzing the study by examining the stationary properties of the variable in question so as to avoid biased, spurious and misleading outcomes. Also, in analyzing the long run correlation between exchange rate and the exogenous variables, the 
Autoregressive Distributed Lag (ARDL) bounds test was employed. The choice of the ARDL model is based on its efficiency in small sample size as in this study (29 observations) and the possibility of the variables having a different optimum number of lags. The ARDL also allows for cointegration estimation by the use of the Ordinary Least Square (OLS) after identifying the lag of the model [30]. In testing the long run correlation between exchange rate and the independent variables, the bound test procedure was applied for cointegration by estimating the following conditional (restricted) version of the ARDL model.

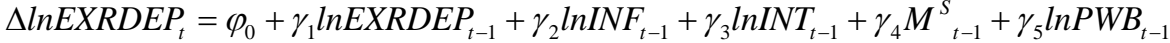

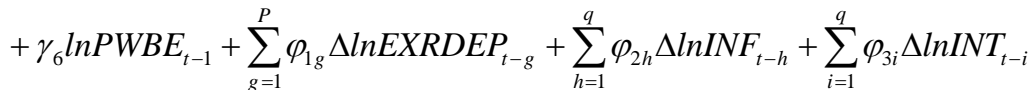

$$
\begin{aligned}
& +\sum_{j=1}^{q} \varphi_{4 j} \Delta \ln M_{t-j}^{S}+\sum_{k=1}^{q} \varphi_{5 k} \Delta \ln P W B_{t-k}+\sum_{l=1}^{q} \varphi_{6 l} \Delta \ln P W B E_{t-l}+u_{t}
\end{aligned}
$$

where $\varphi_{i}$ on the difference of the independent variables are the short run multipliers/dynamics of the model to be estimated through the Error Correction Model (ECM), while $\gamma_{i}$ denotes the long run multipliers. The term $\varphi_{0}$ is the $\mathrm{drift} /$ constant and $u_{t}$ is the error term.

There are three (3) steps involved in the ARDL bound test procedure. The first step is testing for the presence of long run relationship among the variables by estimating Equation (2) by the OLS. In so doing, F-Test is conducted for the joint significance of the numerical values of the lagged levels of the variables.

The study hypothesized that; $H_{0}=\gamma_{1}=\gamma_{2}=\gamma_{3}=\gamma_{4}=\gamma_{5}=\gamma_{6}=0$ (not cointegrated/no long run effect or relationship); $H_{0}=\gamma_{1}=\gamma_{2}=\gamma_{3}=\gamma_{4}=\gamma_{5}=\gamma_{6} \neq 0$ A test for cointegration is provided by two asymptotic critical values where the independent variables are $I(d)$ (where $0 \leq d \leq 1$ ). The explanatory variables are assumed to be integrated of order zero, I ( 0 ) by the lower bound values and integrated of order one, I (1) by the upper bound values. The null hypothesis of no cointegration is rejected if the F-statistics is above the upper bound and accepted if it falls below the lower bound. It, however, remains inconclusive if it lies between the lower and the upper bound critical values.

The second stage is to test the long run relationship after establishing the presence of cointegration. The restricted version of the ARDL long run model for exchange rate are presented below.

$$
\begin{aligned}
& \operatorname{lnEXRDEP} P_{t}=\varphi_{0}+\sum_{i=1}^{P} \gamma_{1} \ln E X R D E P_{t-1}+\sum_{i=1}^{q 1} \gamma_{2} \operatorname{lnINF_{t-1}}+\sum_{i=1}^{q 2} \gamma_{3} \operatorname{lnINT} T_{t-1}+\sum_{i=1}^{q 3} \gamma_{4} \ln M_{t-1}^{S} \\
& +\sum_{i=1}^{q 4} \gamma_{5} \ln P W B_{t-1}+\sum_{i=1}^{q 5} \gamma_{6} \ln P W B E_{t-1}+\mu_{t}
\end{aligned}
$$

The third step in the ARDL model to detect the short run dynamics of the parameters is the estimation of an Error-Correction Model (ECM) to reconcile with the long run evaluates. This is presented below.

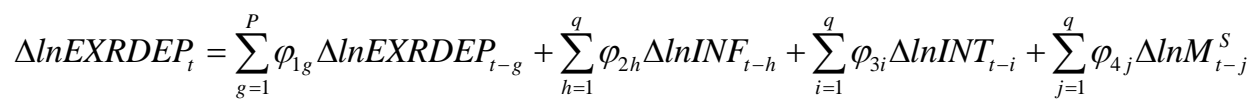

$$
\begin{aligned}
& +\sum_{k=1}^{q} \varphi_{5 k} \Delta \ln P W B_{t-k}+\sum_{l=1}^{q} \varphi_{6 l} \Delta \ln P W B E_{t-l}+\rho E C M_{t-1}
\end{aligned}
$$


The convergence of the short run dynamics coefficients of the model to equilibrium are denoted by $\varphi_{i}$ in Equation (4). The Error-Correction Model is $E C M_{t-1}$ and $\rho$ is its coefficient which measures the adjustment speed of short run convergence to long run equilibrium in the event of a shock to the system.

Lastly, following the establishment of the existence of cointegration, the causal link between the three variables; public sector wage bill, inflation, and exchange rate is determined using the Granger causality test. Granger causality mainly investigates whether a variable is predicted by the past values of another variable. For instance, if a variable such as $\mathrm{Y}$ is regressed on other variables and its own past or lagged values, including the lagged values of other variables say $\mathrm{X}$ that leads to a significant improvement in $\mathrm{Y}$, then $\mathrm{X}$ Granger causes $\mathrm{Y}$ and vice versa. This test is presented below.

$$
\begin{aligned}
& \operatorname{EXRDEP}_{t}=\tau_{10}+\sum_{i=1}^{P} \tau_{11}^{i} \operatorname{EXRDEP}_{t-1}+\tau_{12}^{0} I N F_{t}
\end{aligned}
$$

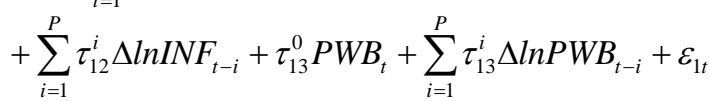

$$
\begin{aligned}
& I N F_{t}=\tau_{20}+\tau_{21}^{0} E X R D E P_{t}+\sum_{i=1}^{P} \tau_{21}^{i} E X R D E P_{t-1}
\end{aligned}
$$

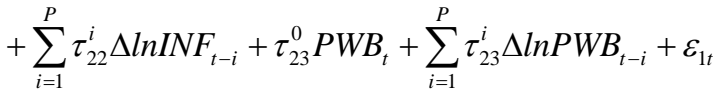

$$
\begin{aligned}
& P W B_{t}=\tau_{30}+\tau_{31}^{0} E_{X R D E P_{t}}+\sum_{i=1}^{P} \tau_{31}^{i} \operatorname{EXRDEP}_{t-1}+\tau_{32}^{0} I N F_{t}
\end{aligned}
$$

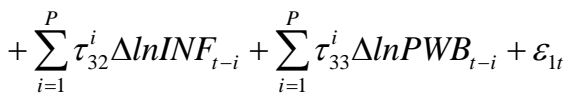

The hypothesis would be:

$$
\begin{aligned}
& H_{0}: \tau_{a i}^{1}=\tau_{a i}^{2} \cdots=\tau_{a i}^{P}=0 \\
& H_{1}: \tau_{a i}^{1}=\tau_{a i}^{2} \cdots=\tau_{a i}^{P} \neq 0
\end{aligned}
$$

The null hypothesis, $H_{0}$ states the non-causality from the independent variable to the dependent variable and the alternative hypothesis shows the causality from the independent variable to the dependent variable. The null hypothesis following F-distribution is accepted if the sum of the coefficients of the variable in question is statistically equal to zero otherwise, it is rejected.

\section{Empirical Results and Discussion}

\subsection{Tests for Stationarity}

Table 1 presents the outcomes of Augmented Dickey-Fuller (ADF) test for unit root.

It was observed from Table 1 that only inflation, exchange rate depreciation and money supply were stationary at the log levels. However, at the first difference, all the variables were stationary at $1 \%$ significance level.

\subsection{Test for Long-Run Relationship}

After establishing the stationarity status of all the variables, the study tested for 
Table 1. Unit root test results.

\begin{tabular}{ccc}
\hline Variables & Log Level & First Difference \\
\hline $\ln I N F$ & $-2.828548^{*}$ & $-6.131881^{* * *}$ \\
$\ln E X R D E P$ & $-2.767253^{*}$ & $-6.105646^{* * *}$ \\
$\ln P W B$ & -0.393869 & $-4.699567^{* * *}$ \\
$\ln M S$ & $-4.608012^{* * *}$ & $-5.149442^{* * *}$ \\
$\ln P W B E$ & -1.727693 & $-7.433020^{* *}$ \\
$\ln I N T$ & -1.318369 & $-4.757814^{* * *}$ \\
\hline
\end{tabular}

Note: the rejection of the null hypothesis of a unit root/non-stationarity is indicated by ${ }^{* *},{ }^{* *},{ }^{*}$ at $1 \%, 5 \%$, and $10 \%$ significance level respectively.

Table 2. ARDL Bounds Test for Cointegration Results.

\begin{tabular}{ccccc}
\hline F-Statistic & Significance Level & Lower Bound & Upper Bound & Cointegration Status \\
\hline \multirow{2}{*}{5.198317} & $10 \%$ & 2.26 & 3.35 & \\
& $5 \%$ & 2.62 & 3.79 & Cointegrated \\
& $1 \%$ & 3.41 & 4.68 & \\
\hline
\end{tabular}

Table 3. Estimated ARDL long run results.

\begin{tabular}{ccccc}
\hline \multicolumn{2}{c}{ Dependent Variable: $\operatorname{lnEXRDEP}$} & & & \\
\hline Regressors & Coefficient & Std. Error & t-Statistic & Prob. \\
\hline $\ln I N F$ & -4.273737 & 1.047363 & -4.080475 & 0.0028 \\
$\ln I N T$ & 4.039383 & 0.682820 & 5.915739 & 0.0002 \\
$\ln M S$ & 1.846831 & 0.653507 & 2.826031 & 0.0199 \\
$\operatorname{In} P W B$ & -4.400302 & 1.229335 & -3.579416 & 0.0059 \\
$\ln P W B E$ & -1.214298 & 0.974636 & -1.245899 & 0.2443 \\
Constant & 8.702054 & 5.813083 & 1.496977 & 0.1686 \\
\hline
\end{tabular}

the presence of long run correlation among the variables by means of Autoregressive Distributive Lag (ARDL) Bounds test approach. The results are presented in Table 2.

The Bounds test results indicated the existence of the long run relationship between exchange rate depreciation and the explanatory variables since the FStatistic exceeds the upper critical values at $5 \%$ significance level.

\subsection{Long Run Results}

Results in Table 3 were estimated to determine the long run connection between exchange rate depreciation (the dependent variable) and its respective exogenous variables.

Debatably, inflation was found to be negatively related to exchange rate depreciation in the long run as observed in Table 3. It assumed a negative coefficient of -4.273737 at $5 \%$ significance level of error. If inflation increases by $1 \%$, exchange rate appreciates by approximately $4.27 \%$. Contrary to theoretical ex- 
pectation, the result purported that increases in the general price level of goods and services impose a long-run appreciating effect on the cedi exchange rate. This may suggest that Ghanaians' demand for locally produced goods remain highly inelastic. As such, their demand for foreign goods does not go up and foreign demand for local goods fails to fall as they are less responsive to price changes. By implication, the demand for both export and import remain highly inelastic defiling Lipsey's plethora view that local inflation raises the quantity of imports. The result is in line with the findings of Kashif [22] that, there is a strong negative relationship between inflation and exchange rate in Pakistan but contradicts the findings of Mumuni and Owusu-Afriyie [21] and Immurana et al. [24] in Ghana.

Interest rate in coherence with economic theory relates positively to exchange rate depreciation in the long run. Its coefficient was positive and statistically significant at $1 \%$. Increase in the interest rate by $1 \%$ leads to an appreciation in the value of the cedi by $4 \%$ in the long run. The result supports the economic theory which postulates that an increase in interest rate leads to an increase in return on assets for foreign investors. If interest rate increases in a particular country, investors see a possible increase in return on assets. Mostly, they are attracted to invest in that country which raises the demand for that country's currency. As a result, an increase in the demand for the domestic currency will lead to an appreciation of its currency. This is similar to Dornbusch's [31] sticky price and Mundell-Fleming fixed-price model referenced in Mumuni \& Owusu-Afriyie [21] that increased interest rate attracts foreign investment that leads to currency appreciation.

Money supply growth in Ghana also has a long run positive correlation with exchange rate depreciation. The positive coefficient of the money supply at $5 \%$ significant error implies that an expansion in the money supply by $1 \%$ increases exchange rate depreciation by $1.85 \%$ in the long run. Thus, money supply growth has a long run depreciating effect on the cedi. The findings of Mumuni \& Owusu-Afriyie (2004 [21]), and Bawumia and Abradu-Otoo [20] that expansion in money supply increases exchange rate depreciation in Ghana support this result.

Public sector wage per GDP has a long run significant negative relationship with exchange rate depreciation in Ghana. As public sector wage bill-GDP rises by $1 \%$, exchange rate depreciation falls by approximately $4.4 \%$. It must be concluded that increased public wage bill in terms of GDP induces a decrease in exchange rate depreciation in Ghana and has a more significant long run negative effect. In the words of Keynes [29], Agénor and Hoffmaister [32], Mihaljek and Saxena [33], and Perry and Cline [6], inflation is the result of cost pressure emanating from wages. It must be reasoned from this that the negative impact of inflation on the value of the cedi influences the relationship between public wage bill and exchange rate depreciation in the long run. That is to say, high wage inflation exerts a depreciating impact on the cedi exchange rate.

Public sector wage bill as a percentage of total government expenditure has an 
insignificant long run negative relationship with exchange rate depreciation. A percentage rise in public sector wage bill as a percentage of government expenditure decreases exchange rate depreciation by approximately $1.2 \%$. It must be established that increased public wage bill in terms of government expenditure induces a decrease in exchange rate depreciation. This also mirrors the significant long run contribution of public wages to inflation in Ghana. It is, therefore, logical to hold from this that the negative impact of inflation on exchange rate depreciation influences the relationship between public wage bill and exchange rate depreciation in the long run. Inferentially, high wage-inflation imposes a depreciating effect on the cedi.

\subsection{Short Run Error Correction Results}

The short run error correction model was estimated to identify the short run dynamics of the variables. The results are presented in Table 4.

Unlike the long run estimates, inflation assumed the expected positive sign in the short run rendering it positively related to exchange rate depreciation in Ghana. The inflation coefficient, however, was statistically insignificant meaning it has no effect on exchange rate depreciation in the short-run. The exchange rate is expected to depreciate further by some $0.55 \%$ resulting from one percent rise in inflation. But at a period lag, inflation exhibited a statistically significant positive relationship with exchange rate depreciation as $1 \%$ rise in inflation increases exchange rate depreciation by about $0.86 \%$. This implies past inflation at one period imposes a significant positive impact on the depreciation of the cedi. By implication, increased local inflation increases the demand for imports. This increases the supply of the cedi to acquire foreign currency for imports. This re-

Table 4. Estimated ARDL short run results.

\begin{tabular}{ccccc}
\hline Dependent Variable: $\ln E X R D E P$ & & & \\
\hline Regressors & Coefficient & Std. Error & t-Statistic & Prob. \\
$D I n I N F$ & 0.553699 & 0.357791 & 1.547551 & 0.1561 \\
$D \operatorname{lnINF-1}$ & 0.864176 & 0.315064 & 2.742863 & 0.0227 \\
$D \ln I N F-2$ & 1.345498 & 0.270355 & 4.976782 & 0.0008 \\
$D \ln I N T$ & 3.821229 & 0.581628 & 6.569886 & 0.0001 \\
$D \ln M S$ & 1.014301 & 0.288489 & 3.515908 & 0.0066 \\
$D \ln M S-1$ & -1.545780 & 0.295181 & -5.236725 & 0.0005 \\
$D \ln P W B$ & -4.516009 & 1.696661 & -2.661705 & 0.0260 \\
$D \ln P W B-1$ & -3.953166 & 1.466276 & -2.696058 & 0.0246 \\
$D \ln P W B E$ & 7.002851 & 1.807798 & 3.873690 & 0.0038 \\
$D \ln P W B E-1$ & 7.914721 & 1.351665 & 5.855533 & 0.0002 \\
$D \ln P W B E-2$ & 5.282096 & 1.956133 & 2.700274 & 0.0244 \\
$E C M(-1)$ & -0.945993 & 0.149633 & -6.322106 & 0.0001 \\
$R^{2}=0.955359, \bar{R}^{2}=0.8759997, F(12.03799)=0.000336, D W=1.797986$ & \\
\hline
\end{tabular}


sults in the fall in the value of the cedi. This is similar to the result of Ebiringa and Anyaogu [34].

Interest rate maintained its positive relationship with the depreciation of exchange rate in the short run period just as in the long run as theory predicts. It was found to be statistically significant at $1 \%$. One percent increase in interest rate appreciates the cedi by $3.82 \%$ in the short run as against $4 \%$ in the long run. From the estimated results, interest rate affects exchange rate depreciation more in the long run than in the short run in Ghana. The result controverts the findings of Hnatkovska et al. [35], Kin and Courage [36], and Ebiringa and Anyaogu [34].

Likewise, money supply just as in the long run sustained its positive correlation with exchange rate depreciation in the short run. Its coefficient remained positive and statistically significant at $1 \%$. Monetary expansion by $1 \%$ worsens exchange rate depreciation by $1.01 \%$ as against $1.85 \%$ in the long run. Also, expansion in money supply depreciates the cedi more in the long run than in the short run. The result contradicts the finding of Ali, Mahmood, and Bashir [25].

Again, public wage bill as a percentage of GDP also upheld its consistency in the short run. It correlated negatively with exchange rate depreciation. It assumed a negative coefficient at $5 \%$ significance level. The result revealed that an increase in public wage bill by $1 \%$ leads to a decrease in exchange rate depreciation by $4.52 \%$. Thus, an increase in public wage bill in terms of GDP significantly deteriorates the exchange rate depreciation both in the short run and long run periods.

Contrary to the long run results, public wage bill as a percentage of government expenditure correlated positively with exchange rate depreciation in the short run. Interestingly, it has the highest coefficient of 7.002851 at $5 \%$ significance level. The implication of this is that a percentage rise in public wage bill in terms of government expenditure appreciates the cedi by $7 \%$. Thus, public sector wage bill as a percentage of government expenditure has the highest appreciating effect on the cedi in the short run. This could result from the fact that when the composition of wage bill on government expenditure increases, the pressure on fiscal balance influences macroeconomic variables such as interest rate depending on how it is financed. If it is financed by issuing securities, interest rate increases and the cedi also appreciates, all things being equal.

From Table 4, the short run model exhibited convergence to equilibrium in the long run out of a temporal shock. The coefficient of the error correction term was negative and statistically significant at $1 \%$. The ECM coefficient of -0.945993 implies $95 \%$ of disequilibrium out of the shock in the previous year converges back to equilibrium in the long run. This value is very high which means that any disequilibrium within the short run exchange rate volatility dynamics in Ghana is quickly adjusted and converged back to equilibrium in the long run.

\section{Granger Causality Test}

Granger causality test was conducted to ascertain the causal relation between exchange rate depreciation, inflation and public wage bill-GDP. The results are 
Table 5. Granger causality test results.

\begin{tabular}{cccc}
\hline Pairwise Granger Causality Tests & & & \\
\hline Null Hypothesis: & Obs. & F-Statistic & Prob. \\
\hline LNINF does not Granger Cause LNEXRDEP & 26 & 1.07737 & 0.3824 \\
LNEXRDEP does not Granger Cause LNINF & & 3.86186 & 0.0259 \\
LNPWB does not Granger Cause LNEXRDEP & 26 & 0.07079 & 0.9749 \\
LNEXRDEP does not Granger Cause LNPWB & & 0.07690 & 0.9717 \\
LNPWB does not Granger Cause LNINF & 26 & 0.81295 & 0.5024 \\
LNINF does not Granger Cause LNPWB & & 3.10529 & 0.0510 \\
\hline
\end{tabular}

presented in Table 5.

It was found in Table 5 that the null hypothesis of no causality running from inflation to exchange rate depreciation was accepted at 5\% significance level. This means the coefficient is statistically equal to zero and the P-value is greater than the $5 \%$ significance level. There is a unidirectional causality from exchange rate depreciation to inflation. Thus, exchange rate depreciation Granger-causes inflation with no feedback. Hence, the past and present values of exchange rate depreciation provide vital information in predicting the future values of inflation in Ghana.

In addition, the null hypothesis of no causality between public wage bill-GDP and exchange rate depreciation was also accepted at $5 \%$ significance level in both cases. This implies that their coefficients are statistically not equal to zero and their P-values are greater than the 5\% significance level. There is, therefore, no bidirectional or reversal causality such that public wage bill-GDP and exchange rate depreciation do not Granger cause each other. Their past and present values offer no vital information in predicting the future values of each other in Ghana.

Lastly, the null hypothesis that public wage bill does not Granger cause inflation was accepted at $5 \%$ level of significance. However, the null hypothesis of no causality from inflation to public wage bill-GDP was rejected implying it does not have a coefficient statistically equal to zero and a P-value less than $10 \%$ level of significance. Thus, there is a unidirectional causality running from inflation to public wage bill with no feedback. Inflation Granger causes public wage bill but public wage bill does not Granger cause inflation.

\section{Conclusions and Policy Recommendations}

Continuous depreciation of the cedi has been in the orbit of concern of policy makers for time immemorial. This is because, in spite of many policy actions to restore the continuous depreciation of the cedi amidst wage hikes and inflation, the efforts of policy makers seem to thwart in vain. The ARDL method was empirically used to determine whether the rising public sector wage bill and inflation have any impact on the value of the cedi over the period 1986 to 2014. The study discovered that inflation, money supply, interest rate and public sector wage bill have significant impact on exchange rate in the Ghanaian economy. 
The outcome of this study postulated that exchange rate determination in Ghana is also a fiscal phenomenon in spite of the significant and domineering role played by monetary expansion.

Based on the findings, the paper proposed that equal attention must be accorded both fiscal and monetary policy in exchange rate stabilization. It, therefore, suggested that there must be a purely independent central bank; devoid of political appointments and interference to carry out its mandate with free hands.

An independent non-political fiscal body like the monetary policy committee under Bank of Ghana must also be established under the same body independent of the Ministry of Finance to undertake the following responsibilities, to ensure wage sustainability through negotiation of public sector wage adjustment subject to budgetary constraints aimed at reducing the wage bill-to-tax revenue, public sector reforms with specific emphasis on right-sizing the public service and policy freeze on employment into some unproductive sectors of the economy, rationalize the wage bill, pensions, gratuities and social security payments as part of measures to reduce the wage bill-to-tax revenue to ECOWAS thresholds.

\section{References}

[1] Parsley, D.C. and Wei, S.J. (2001) Explaining the Border Effect: The Role of Exchange Rate Variability, Shipping Costs, and Geography. Journal of International Economics, 55, 87-105. https://doi.org/10.1016/S0022-1996(01)00096-4

[2] Bleaney, M. (1996) Central Bank Independence, Wage-Bargaining Structure, and Macroeconomic Performance in OECD Countries. Oxford Economic Papers, 48, 20-38. https://doi.org/10.1093/oxfordjournals.oep.a028559

[3] Krugman, P. (1988) Exchange Rate Instability. The MIT Press, Cambridge.

[4] Albuquerque, C.R. and Portugal, M.S. (2004) Exchange Rate and Inflation: A Case of Grumpiness of Volatility. www.sebh.ecn.br

[5] Flood, R.P. and Rose, A.K. (1995) Fixing Exchange Rates a Virtual Quest for Fundamentals. Journal of Monetary Economics, 36, 3-37.

https://doi.org/10.1016/0304-3932(95)01210-4

[6] Perry, N. and Cline, N. (2013) Wages, Exchange Rates, and the Great Inflation Moderation: A Post Keynesian View. Working Paper No. 759, Levy Economics Institute, 1-28. https://doi.org/10.2139/ssrn.2236208

[7] Marfo, Y.O. (2012) The State of the National Currency-The Ghana CEDI. Published by the Chronicle.

[8] Bawumia, M. (2013): Discipline in Economic Management: The Key to Sustainable Growth and Prosperity-The Economy. Published by the B \& F Times.

[9] Bernanke, B.S., Boivin, J. and Eliasz, P. (2005) Measuring the Effects of Monetary Policy: A Factor-Augmented Vector Autoregressive (FAVAR) Approach. The Quarterly Journal of Economics, 120, 387-422. https://doi.org/10.1162/0033553053327452

[10] Asiama, J., Akosah, N. and Owusu-Afriyie, E. (2014) An Assessment of Fiscal Sustainability in Ghana. Bank of Ghana Research Working Paper, WP/BOG-2014/09, 1-33.

[11] Ministry of Finance (2013) The Budget Statement and Economic Policy of the Government of Ghana for the 2014 Financial Year. www.mofep.gov.gh

[12] International Monetary Fund (2005) Ghana Country Report No. 05/286. IMF, Wa- 
shington DC.

http://www.imf.org/external/ns/search.aspx?NewQuery=International+Monetary+F und $+\% 282005 \% 29 .+$ Ghana+Country+Report+No.+05\%2F $286 .+$ Washington $\% 2 \mathrm{C}+$ DC\%3A+IMF\&submit

[13] Canzoneri, M.B., Cumby, R.E. and Diba, B.T. (2005) Price and Wage Inflation Targeting: Variations on a Theme by Erceg, Henderson, and Levin. Proceedings of Board of Governors of the Federal Reserve System, Washington DC, 29-30 September 2005, 181-215.

[14] Friedman, M. (1968) Inflation: Causes and Consequences. In: Friedman, M., Ed., Dollars and Deficits. Living with America's Economic Problems, Prentice Hall, Englewood Cliffs, 21-71.

[15] Ekanayake, H.K. (2012) The Link between Fiscal Deficit and Inflation: Do Public Sector Wages Matter? Australia South Asia Research Centre, 14, 1-34.

[16] Ofori-Abebrese, G. (2008) Economics of the Monetary System. Vytal Print, Kumasi.

[17] Bilson, J.F. (1978) The Monetary Approach to the Exchange Rate: Some Empirical Evidence. Staff Papers, 25, 48-75. https://doi.org/10.2307/3866655

[18] Roos, F. (1985) De vorming van de wisselkoers. Mededelingen der Koninklijke Nederlandse Akademie van Wetenschappen, afd. Letterkunde, Nieuwe Reeks, deel 48 No. 2, Noord-Hollandsche Uitg. Mij., Amsterdam.

[19] Osei-Assibey, E. (2013) Exchnage Rate, Interest Rate and Inflation in Ghana: Is there a Missing Ling. Department of Economics, University of Ghana, Legon-Accra.

[20] Bawumia, M. and Abradu-Otoo, P. (2003) Money Growth, Exchange Rate and Inflation in Ghana: An Error Correction Analysis. Bank of Ghana Working Paper, WP/ BOG-2003/05.

[21] Mumuni, Z. and Owusu-Afriyie, E. (2004) The Determinants of Cedi/Dollar Rate of Exchange in Ghana: A Monetary Approach. WP/ BOG-2004/06, 1-23.

https://www.bog.gov.gh/privatecontent/Research/Working\%20Papers/Exchange\%2 0Rate\%20Determination06.pdf

[22] Kashif, S. (2011) The Relationship between Inflation and Exchange Rate in Pakistan. http://economics.fundamentalfinance.com/exchange-rate-and-inflation-in-pakistan .php

[23] Madesha, W., Chidoko, C. and Zivanomoyo, J. (2013) Empirical Test of the Relationship between Exchange Rate and Inflation in Zimbabwe. Journal of Economics and Sustainable Development, 4, 52-58.

[24] Immurana, M., Iddrisu, A.A. and Kyei-Brobbey, I. (2013) The Determinants of the Real Exchange Rate in Ghana: A Focus on Inflation Using a Bound Test Approach, Journal of African Development and Resources Research Institute, 3, 20-37.

[25] Ali, T.M., Mahmood, M.T. and Bashir, T. (2015) Impact of Interest Rate, Inflation and Money Supply on Exchange Rate Volatility in Pakistan. World Applied Sciences Journal, 33, 620-630.

[26] World Bank (2007) The World Bank's Administrative and Civil Service Reform Website. World Bank. http://web.worldbank.org/WBSITE/EXTERNAL/TOPICS/EXTPUBLICSECTORA NDGOVERNANCE/EXTADMINISTRATIVEANDCIVILSERVICEREFORM/0,me nuPK:286372 pagePK:149018 piPK:149093 theSitePK:286367,00.html

[27] International Monetary Fund, Government Finance Statistics Division (2001) Government Finance Statistics Yearbook. International Monetary Fund.

[28] OECD (2011) Government at a Glance. OECD, Paris. http://www.oecd.org/gov/governmentataglance2011.htm 
[29] Keynes, J.M. (1936) The General Theory of Interest, Employment and Money. Macmillan, London.

[30] Pesaran, M.H., Shin, Y.C. and Smith, R. (2001) Bound Testing Approach to the Analysis of Level Relationship. Journal of Applied Econometrics, 16, 289-326. https://doi.org/10.1002/jae.616

[31] Dornbusch, R. (1976) Expectations and Exchange Rates Dynamics. Journal of Political Economy, 84, 1161-1176. https://doi.org/10.1086/260506

[32] Agénor, P.R. and Hoffmaister, M.A.W. (1997) Money, Wages and Inflation in Middle-Income Developing Countries. International Monetary Fund Working Paper No. 97-174.

[33] Milhajek, D. and Saxena, S. (2009) Wages, Productivity and Structural Inflation in Emerging Market Economies. Bank for International Settlements (BIS) Papers No. 49, 1-389.

[34] Ebiringa, O.T. and Anyaogu, N.B. (2014) Exchange Rate, Inflation and Interest Rates Relationships: Autogressive Distributive Lag Analysis. Journal of Economics and Development Studies, 2, 263-279.

[35] Hnatkovska, V., Lahiri, A. and Vegh, C.A. (2013) Interest Rate and the Exchange Rate: A Non-Monotonic Tale. European Economic Review, 63, 68-93. https://doi.org/10.1016/j.euroecorev.2013.06.001

[36] Kin, S. and Courage, M. (2014) The Impact of Oil Prices on the Exchange Rate in South Africa. Journal of Economics, 5, 193-199.

Submit or recommend next manuscript to SCIRP and we will provide best service for you:

Accepting pre-submission inquiries through Email, Facebook, LinkedIn, Twitter, etc. A wide selection of journals (inclusive of 9 subjects, more than 200 journals)

Providing 24-hour high-quality service

User-friendly online submission system

Fair and swift peer-review system

Efficient typesetting and proofreading procedure

Display of the result of downloads and visits, as well as the number of cited articles

Maximum dissemination of your research work

Submit your manuscript at: http://papersubmission.scirp.org/

Or contact tel@scirp.org 